\title{
PERSPECTIVE
}

\section{Analysis of ocular fluids for local antibody production in uveitis}

\author{
J H de Boer, L Luyendijk, A Rothova, A Kijlstra
}

Uveitis or intraocular inflammation is a potentially blinding disorder that is initiated by a diverse group of diseases. Concepts of uveitis have evolved rapidly over the past few years, but many questions about the aetiology still remain unanswered. Uveitis is associated with several systemic diseases but the frequency of systemic diseases among uveitis patients is dependent on age of onset and type of uveitis. ${ }^{12}$ In a white population the most common systemic disorders associated with uveitis are seronegative spondylarthropathy and sarcoidosis. ${ }^{3}$ Several types of uveitis are associated with histocompatibility leucocyte antigens (HLA) - for instance, acute anterior uveitis with HLA B27 and birdshot chorioretinopathy with HLA A29. ${ }^{4}$ The reason why these HLA types increase the relative risk for uveitis is unclear but in the case of HLA B27 infections with Gram negative bacteria might be an influence. ${ }^{5}$ Autoimmune mechanisms are also thought to participate in the pathogenesis of uveitis since the eye harbours autoimmune inducing or uveitogenic material such as retinal S-antigen and interphotoreceptor retinoid binding protein. ${ }^{4}$ After immunisation with adjuvants these antigens induce ocular inflammation in several species. Infectious diseases might indirectly play a role in autoimmune uveitis by triggering the immune response against autoantigens. ${ }^{4}$ Furthermore, infectious diseases are able to induce directly intraocular inflammation. ${ }^{6}$ The retina consists of neural tissue, making it particularly prone to infection with neurotropic organisms such as Toxoplasma gondii and herpesviruses. Other infectious diseases that can induce uveitis are tuberculosis, syphilis, and Lyme borreliosis. In some forms of infectious uveitis - for example, ocular toxoplasmosis, autoimmune mechanisms are thought to participate in the ocular manifestations of the disease. ${ }^{7-9}$

Discrimination between the infectious or non-infectious aetiology of uveitis is important since the treatment is different. Immunosuppressive therapy is often essential but it might be deleterious in direct infectious uveitis entities without specific antimicrobial treatment. In various infectious ocular diseases, such as ocular toxoplasmosis or acute retinal necrosis, there are no signs of a systemic infection. Investigation of serum antibody titres therefore gives little if any information about the aetiology of the uveitis. ${ }^{1011}$ Instead of looking in the general circulation, it might be more informative to analyse samples obtained at the site of inflammation. For more than a century the aqueous humour of patients with uveitis has been analysed for the presence of infectious agents. ${ }^{12}$ The first studies of aqueous humour included analysis of cytopathological and bacteriological investigation of the aqueous humour of patients with uveitis or endophthalmitis but the results of the studies were not conclusive. ${ }^{12-14}$ In 1943, Amsler and Verrey ${ }^{13}$ reported phagocytosis of bacilli and cocci by cells in the anterior chamber in $20 \%$ of patients with uveitis, which was in contrast with the results of other studies in which bacterial agents were only occasionally detected in the aqueous humour. ${ }^{13-15}$ Micro-organisms were only sporadically cultured from the aqueous humour but in positive cases contamination could not be excluded with certainty.

A new approach for the detection of infectious agents in uveitis is the analysis of ocular fluids by the polymerase chain reaction (PCR). In this technique the DNA of infectious agents can be amplified and detected. The advantages over viral cultures are an increased sensitivity and rapidly available results.

Cytological studies of aqueous humour and vitreous fluid revealed that lymphocytes were the most common inflammatory cells in infectious as well as non-infectious uveitis, whereby the number of $T$ lymphocytes exceeded that of B lymphocytes. ${ }^{16-18}$ In vitreous fluid, the majority of the $T$ cells were $\mathrm{CD} 4+.{ }^{18}$ In infectious uveitis the number of neutrophils and macrophages were more pronounced than in uveitis without an infectious aetiology. ${ }^{18}$

The humoral immune response in ocular fluids against several infectious agents has been investigated more extensively. Detection of specific antibodies in ocular fluids may give an indirect indication of the micro-organisms responsible for the intraocular inflammation and may thus confirm a suspected clinical diagnosis. However, antibodies in the eye during uveitis can be derived from two sources: blood by disruption of the blood-aqueous barrier or intraocular B cells. Goldmann and Witmer reported a method to calculate whether specific antibodies present in aqueous humour during uveitis were produced locally. ${ }^{19}$ For this study they used two models: leptospirosis in horses and experimental ocular tuberculosis in rabbits. The titres of specific antibodies in aqueous humour and

Table 1 Results of studies on infectious agents in ocular fluids in uveitis

\begin{tabular}{|c|c|c|c|c|c|}
\hline \multirow[b]{2}{*}{ Infectious agents } & \multicolumn{4}{|c|}{ Detection in ocular fluids } & \multirow[b]{2}{*}{ References } \\
\hline & $\begin{array}{l}\text { Micro- } \\
\text { organism }\end{array}$ & Antigen & Antibodies & $D N A$ & \\
\hline \multicolumn{6}{|l|}{ Parasites } \\
\hline Toxoplasma gondii & + & & + & + & $22-33,91$ \\
\hline Varicella zoster virus & + & + & + & + & $10,38-46$ \\
\hline Herpes simplex virus 1 & + & + & + & + & $44-51,60$ \\
\hline Herpes simplex virus 2 & - & & + & + & 47 \\
\hline Cytomegalovirus & + & + & + & + & $\begin{array}{l}20,54,55- \\
60\end{array}$ \\
\hline Epstein-Barr virus & & & + & & $68-70$ \\
\hline Human herpes virus 6 & & & - & $+^{\star}$ & $\begin{array}{l}72,73 \text {, this } \\
\text { review }\end{array}$ \\
\hline Measles & & & + & & 75 \\
\hline Adenovirus & & & + & & 36,78 \\
\hline Parvo B19 virus & & & - & & 78 \\
\hline Human $\mathrm{T}$ cell & & & & & \\
\hline lymphotropic virus & & & & + & 77 \\
\hline \multicolumn{6}{|l|}{ Bacteria } \\
\hline Chlamydia trachomatis & & & - & & 20 \\
\hline Mycobacterium tuberculosis & & & - & & \\
\hline Streptococcus & & & - & & 36 \\
\hline Borrelia burgdorferi & & & - & & This review \\
\hline $\begin{array}{l}\text { Treponema pallidum } \\
\text { Leptospira }\end{array}$ & + & & + & & $\begin{array}{l}85,86 \\
88\end{array}$ \\
\hline
\end{tabular}

+ Indicates publication of positive results; - indicates publication of negative results.

$\star$ Present in the retina. 
serum were compared with the total immunoglobulin content in aqueous humour and serum resulting in the Goldmanin-Witmer coefficient ${ }^{19}$ :

$\mathrm{C}=\frac{\text { antibody titre aqueous humour or vitreous fluid }}{\text { antibody titre serum }} \times \frac{\text { total IgG aqueous humour or vitreous fluid }}{\text { total IgG serum }}$

Local antibody production was defined when the coefficient was greater than or equal to 1 , indicating a larger proportion of specific antibodies per total immunoglobulin in the eye than in the serum. However, we and other investigators have observed that a coefficient of between 1 and 3 may occur in controls. ${ }^{202124}$ Therefore, in view of the variability of several tests, most investigators consider coefficients of 3 or more as positive for local antibody production. ${ }^{20} 21$ Furthermore, the ratio of the coefficients for two different viruses is defined as coefficient' $\left(C^{\prime}\right)$. It has been suggested that by using the combination $C$ and $C^{\prime}$ false positive results, caused by polyclonal B cell activation, are eliminated. ${ }^{20}$ The ratio for $\mathrm{C}^{\prime}$ is defined to be positive when it was equal to or exceeded 4.

Here we give an overview of studies in which ocular fluids were analysed to detect an infectious aetiology of uveitis (Table 1) and will include results obtained from our own laboratory.

\section{Paracentesis}

Aqueous or vitreous analysis is becoming indispensable especially for the infectious types of uveitis. An anterior chamber paracentesis is an easily performed procedure, which yields about $150-200 \mu$ l fluid. The procedure is usually performed under local anaesthesia with drops (retrobulbar anaesthesia is not required) in an outpatient clinic. The patient is in a supine position and preferably the microscope is used. The eyelids are spread with a speculum and the eyeball is fixated with forceps. The puncture is preceded by a peripheral non-penetrating corneal incision using a sharp thin blade. The incision is ended just above Descemet's membrane and the eye is then penetrated easily and without resistance with a 30 gauge needle on a tuberculine syringe. The plunger is either removed before the procedure with the syringe filling up spontaneously, or the assistant pulls up the plunger and aspirates the required amount of fluid. No complications of paracentesis were seen in approximately 300 cases when the procedure was performed by an experienced ophthalmologist (Van der Lely et al, manuscript in preparation).

\section{Parasites}

\section{Toxoplasma gondii}

The first studies concerning the analysis of antitoxoplasma antibodies in ocular fluids were published by $O^{\prime}$ Connor. ${ }^{22} 23$ In one third of the aqueous humour samples of patients with presumed ocular toxoplasmosis a precipitating antibody to Toxoplasma was detected. ${ }^{22} 23$ In 1966, Desmont investigated 859 paired aqueous humour and serum samples of 574 patients for the presence of locally produced anti-toxoplasma antibodies. ${ }^{24}$ The antitoxoplasma antibodies were measured by a modification of the dye test of Sabin and Feldman, while globulin levels were measured by precipitation in liquid or gel. In their control group the coefficients ranged from 0.5 to 2 , and coefficients between 2 and 7 were considered, therefore, to be suggestive of, and coefficients exceeding 8 as definite for, ocular toxoplasmosis. A coefficient higher than 2 was observed in $33 \%$ of the patients with posterior uveitis and in $24 \%$ of the patients the coefficient exceeded 8 . In five of these patients with unilateral uveitis the aqueous humour of the normal eye was also investigated and the coefficients were negative. A remarkable observation is that positive coefficients (exceeding 8 ) were seen in $1.8 \%$ of the patients with anterior uveitis. It is not yet clear whether Toxoplasma can induce anterior uveitis without involvement of the posterior segment in immunocompetent individuals, but the parasite has been detected in the iris of a patient with AIDS and iridocyclitis. ${ }^{25}$ Normal coefficients were found in eyes with scarred lesions of congenital toxoplasmosis without active inflammation, indicating that recent antigenic stimulation is necessary for the production of local antibodies. Normal coefficients were also observed when paracentesis was performed within 3 weeks after the onset of inflammation and the coefficients of these patients became positive at a later stage in the course of the disease. Other investigators have found local antibody production against Toxoplasma in half of the cases with posterior uveitis $(n=45){ }^{26}$ In our laboratory, a local humoral immune response to Toxoplasma was detected in $74 \%$ of the patients with presumed ocular toxoplasmosis $(n=22$; diagnosis based on clinical features), in $25 \%$ of patients with posterior uveitis of unknown origin $(n=15)$, one patient with AIDS, and none of the controls (32 patients with cataract without ocular inflammation). ${ }^{27-29}$ In this study the sensitivity for the coefficient exceeding 3 for Toxoplasma was $74 \%$ and the specificity $100 \%{ }^{29}$ Baarsma et $a l^{30}$ investigated paired serum and vitreous fluid samples of 24 patients with severe vision-threatening uveitis for the presence of antibodies against herpesviruses and Toxoplasma. Samples of seven patients showed local antibody production against Toxoplasma. One patient with the initial diagnosis of suspected ocular toxoplasmosis appeared to be positive for herpes simplex virus, while one patient with panuveitis of unknown origin was positive for Toxoplasma. In both these cases, the laboratory findings resulted in a change in medical treatment but whether this was of benefit for the course of the uveitis is not mentioned by the authors. ${ }^{30}$

Toxoplasma DNA in aqueous humour has been detected in $18 \%$ and $33 \%$ of patients with active Toxoplasma chorioretinitis ( $n=17$ and $n=22)$, respectively. ${ }^{31} 32$ In the first study, ocular inflammation was present for at least 2 weeks. In both studies there was no correlation between local antibody production and the presence of protozoic DNA which might be explained by the moment of sample collection in the course of the disease. Theoretically, early in the course of the disease, local antibody production might be negative ${ }^{2433}$ despite the detection of protozoic DNA by PCR.

\section{Toxocara canis}

Ocular toxocariasis is caused by an infection with the common dog roundworm. One case of histologically proved ocular toxocariasis was reported with undetectable anti-toxocara antibodies in the circulation indicating that negative serology does not exclude the diagnosis. ${ }^{34}$ Biglan and associates ${ }^{35}$ described five patients with presumed ocular toxocariasis and positive antibody titres against Toxocara in vitreous fluid and the serum. No coefficients were calculated, but in all cases the antibody titres in vitreous fluid were equal to or higher than the titre in the serum, which suggests local antibody production. ${ }^{35}$ In collaboration with the National Institute of Public Health and Environmental Protection, we investigated 26 ocular fluid samples (aqueous humour $\mathbf{n}=7$; vitreous fluid $n=19$ ) of relatively young patients with posterior uveitis, in which the diagnosis of toxocariasis was considered in the differential diagnosis, for the presence of specific antibodies 
Table 2 Anti-toxocara antibodies in aqueous humour and serum and the definite diagnosis

\begin{tabular}{llll}
\hline Patients & $\begin{array}{l}\text { Antibody titre } \\
\text { in serum }\end{array}$ & $\begin{array}{l}\text { Antibodies in } \\
\text { ocular fluid }\end{array}$ & Ocular diagnosis \\
\hline 1 & $1: 80$ & - & Ocular toxocariasis \\
2 & $1: 80$ & - & Retinal pigment epithelial tumour \\
3 & $1: 80$ & + & Ocular toxocariasis \\
4 & - & + & Panuveitis unknown origin \\
5 & - & + & Ocular toxocariasis \\
\hline
\end{tabular}

against Toxocara and Ascaris. Three ocular fluid samples were positive for antibodies against Toxocara in the aqueous humour or vitreous fluid, while in two of these patients no specific antibodies could be detected in the serum. For one of these latter patients, the diagnosis of ocular toxocariasis was doubtful. The aqueous humour and serum samples with specific antibodies against Toxocara of one patient were also positive for antibodies against $A$ scaris. Two additional patients had specific antitoxocara antibodies in the serum but not in the ocular fluid. Finally, three patients were diagnosed as having ocular toxocariasis based on their clinical picture and antibodies against Toxocara in the serum $(n=1)$ or aqueous humour $(n=2)$ (Table 2). None of the patients was diagnosed has having ocular ascariasis. In the follow up of this patient group, in two patients a very rare diagnosis of a pathologically proved retinal pigment epithelial tumour was made and one of these patients was positive for Toxocara in the serum. This illustrates the difficulties in interpretation of serology for Toxocara (Table 2). Three other patients were diagnosed as having ocular toxoplasmosis, which was confirmed by local antibody production against Toxoplasma.

\section{Viruses and microbes}

\section{Herpesviruses}

In order to investigate the aetiology of inflammation, Witmer conducted different tests for the presence of local antibody production on 693 paired aqueous humour and serum samples of patients with uveitis. Samples were tested for tuberculosis with the Middlebrook-Dubos test, for streptococcal disease with the antistreptolysin $\mathrm{O}$ test, for toxoplasmosis with the Toxoplasma dye test and for several viruses with complement fixation tests. ${ }^{36}$ However, in this study the cut off level for the coefficient was 1 , which has lacked sufficient specificity in other studies. ${ }^{21} 29$ None of the samples was positive for the bacterial agents tested, 37 cases had a coefficient for Toxoplasma, and 26 samples showed antibodies against herpes simplex virus (HSV; $n=18)$, varicella zoster virus $(\mathrm{VZV} ; n=3)$, mumps virus $(n=3)$, or adenovirus $(n=2)$. The anatomical localisations of the uveitis in patients with coefficients for Toxoplasma were anterior uveitis $(n=12)$, chorioretinitis $(n=10)$, and panuveitis $(n=15)$. The author does not give an explanation for the large number of patients having anterior uveitis with a positive coefficient for Toxoplasma, but in four of the cases the coefficients were close to 1 , which is not indicative for local antibody production concerning our criteria. ${ }^{27} 29$ The majority of the patients with positive coefficients for viruses had anterior uveitis. Dussaix et al investigated the presence of specific antibodies against Chlamydia trachomatis and herpesviruses in paired serum and aqueous humour samples of 45 selected patients with uveitis and 181 randomised patients with uveitis. Positive results were obtained in $37.7 \%$ of selected cases and $13.3 \%$ of randomised patients. The anatomical type of the uveitis in the positive cases was mainly anterior uveitis or keratouveitis and the majority of cases had local antibody production against HSV. Two cases of anterior uveitis were positive for $\mathrm{CMV}$, but it was not specified whether these patients were immunocompromised or not. None of the patients was positive in aqueous humour for Chlamydia trachomatis. ${ }^{20}$

\section{Varicella zoster virus}

Except from anterior uveitis and keratouveitis, VZV or HSV are thought to be responsible for the majority of cases of acute retinal necrosis (ARN) syndrome. ${ }^{37} \mathrm{VZV}$ has been cultured from vitreous aspirate of a patient with ARN, but viral cultures often remain negative even if electron microscopic examination shows virus particles. ${ }^{38} 39 \mathrm{VZV}$ antigens have also been detected in vitreous cells by immunostaining. ${ }^{40}$ Local antibody production against VZV in ocular fluids and in cerebrospinal fluid of patients with ARN has been reported by several investigators. ${ }^{41} 42$ These studies have recently been reviewed by Pepose et al and they concluded that a viral aetiology could be established in $86 \%$ of subacute and convalescent samples. ${ }^{10}$ In their series the number of samples with a positive coefficient decreased when samples were obtained early in the course of the disease indicating that shortly after the onset of the disease intraocular antibody titres might not have reached a sufficient level to cause a positive coefficient. One patient has been described with high levels of IgM antibodies against VZV in the subretinal fluid obtained during retinal detachment surgery; these antibodies were not detectable in the serum indicating that the IgM antibodies in the eye are locally produced. ${ }^{43} \mathrm{We}$ investigated the presence of local antibody production in aqueous humour or vitreous fluid against herpesviruses and Toxoplasma in a relatively large group of patients with the clinical characteristics of ARN $(n=28) .{ }^{44}$ Intraocular antibody production to VZV or HSV could be established in $57 \%$ of the patients and three patients had a double positive coefficient for VZV as well as HSV. None of the patients was positive for CMV and one patient exhibited a double coefficient for HSV and Epstein-Barr virus. One patient with the clinical characteristics of ARN (extensive peripheral retinal necrosis) appeared to have a positive coefficient for Toxoplasma. We also concluded that the moment of sample collection is crucial since the majority of the negative samples were obtained within 2 weeks or 6 months after the onset of the disease.

Two different studies showed the presence of VZV DNA in aqueous humour or vitreous fluid of patients with ARN. ${ }^{45} 46$ In both studies the same primers against the ecoRI-D fragment of the VZV genome were used. In one of these studies the PCR results were compared with the local antibody production. One aqueous humour sample obtained within 1 week after the onset of the disease was positive for HSV DNA, but the coefficient of HSV was negative. The coefficient for VZV was positive in four vitreous fluid samples obtained later than 3 weeks after the onset of the disease and after treatment with acyclovir, but VZV DNA could only be detected by PCR in one of these samples. ${ }^{45}$ Control samples in both studies were negative for VZV and HSV DNA with PCR. ${ }^{45} 46$

\section{Herpes simplex virus 1 and 2}

HSV type 1 and 2 can both be involved in ARN. ${ }^{47} \mathrm{HSV} 1$ has been isolated from vitreous fluid of patients with ARN, and HSV 1 antigens have been detected in cells from the vitreous fluid by immunostaining. ${ }^{48} 49$ Specific anti-HSV 1 and 2 antibodies have been observed in ocular fluids in this disease, and HSV 2 DNA was also detected in the vitreous fluid by PCR. 4750 
As mentioned above, local antibody production against HSV has been detected in patients with anterior uveitis or keratouveitis. ${ }^{2036}$ Denis $^{51}$ investigated 62 samples of patients with keratitis or uveitis. Thirty patients were clinically recognised as having a herpes infection and two thirds of them had local antibody production against HSV. The majority of these patients had keratitis. In this study, the duration of the infection was of no great importance for the laboratory results but in these series there was chronic inflammation of the cornea. ${ }^{51}$

\section{Cytomegalovirus}

Cytomegalovirus (CMV) is a frequent cause of retinitis in immunocompromised hosts, especially in patients with AIDS or transplant recipients. Except for congenital infections, only a few cases of retinitis caused by CMV have been reported in immunocompetent patients. ${ }^{52} 53 \mathrm{We}$ investigated ocular fluid samples of 261 non-immunocompromised patients for local antibody production against CMV. In six cases a positive coefficient for CMV (2.3\%) was observed and four of these cases exhibited a double coefficient. The diagnosis of these four patients were keratouveitis and chronic anterior uveitis with a double positive coefficient for CMV and VZV, ocular toxoplasmosis with a double positive coefficient for Toxoplasma and CMV, and panuveitis of unknown origin with multiple positive coefficients for CMV, Toxoplasma, and HSV. The two other positive coefficients for CMV were observed in vitreous fluid of a patient with intermediate uveitis and in aqueous humour of a patient with panuveitis after cataract extraction.

CMV has been isolated from ocular fluids of patients with AIDS and with retinitis. ${ }^{5455}$ In our laboratory, local antibody production against CMV in aqueous humour of patients with AIDS and retinitis was detected in $26 \%$ of the cases. ${ }^{21} 29$ In a later study, we experienced that coefficients are most often negative in patients with AIDS despite the presence of CMV DNA in these samples detected by PCR (an article on this study is currently being prepared). Abnormalities in the humoral immune response have been described in patients with AIDS, and specific antibodies might be undetectable despite a pathologically proved infection. ${ }^{56}$ The explanation for the discrepancy in serological results between our studies might be that the patients in the second study were in a more advanced stage of the HIV infection.

Several authors reported detection of CMV DNA in ocular fluids of patients with AIDS and active CMV retinitis. ${ }^{57-60}$. Fox et al also detected CMV DNA in one of the vitreous controls without signs of ocular inflammation. ${ }^{57}$ The detection of latent viruses makes this technique unsuitable for diagnostic purposes to discriminate between CMV retinitis and other uveitis entities. This problem could be solved by the detection of viral messenger RNA instead of DNA, or by the use of quantitative PCR. This latter method determines the number of viral genomes and it has already been used for monitoring ganciclovir treatment in patients with AIDS and CMV retinitis. ${ }^{59}$ Other investigators detected both CMV DNA and HSV DNA in one aqueous humour sample of a patient with AIDS and retinitis by the PCR technique, indicating a double infection. 60

\section{Epstein-Barr virus}

Epstein-Barr virus (EBV) is the major cause of infectious mononucleosis. The prevalence of EBV specific antibodies approaches $100 \%$ in adults. ${ }^{61}$ Ocular involvement during acute infectious mononucleosis mainly affects the outer surface of the eye and anterior segment, ${ }^{62} 63$ although a few cases of retinitis have also been reported. ${ }^{64} 65$ There is also evidence that EBV, without clinical signs of infectious mononucleosis, is involved in the pathogenesis of chorioiditis and panuveitis, but the results of different studies are controversial. ${ }^{66} 67$ In these studies only serum samples were investigated.

Nolle et al could neither detect specific IgG and IgM antibodies against EBV, VZV, and CMV, nor a complement fixation reaction against $\mathrm{HSV}$ in serum and vitreous fluid samples from nine patients with chorioretinitis. ${ }^{68}$ Usui et al detected local IgG antibody production against the viral capsid antigen of EBV in aqueous humour of three cases of bilateral anterior uveitis. The coefficients for EBV ranged from 1 to 18 and in one sample a double positive coefficient was detected for EBV and HSV1.69 Maas et al reported local antibody production against EBV in three patients with intermediate uveitis and also in their series a double positive coefficient for EBV and HSV was observed. ${ }^{70}$ In our laboratory, 472 samples from 421 unselected patients with uveitis were investigated for local antibody production against EBV and a positive coefficient was observed in 13 cases of uveitis. In six of these 13 patients, a double positive coefficient for various herpesviruses or Toxoplasma was observed. One patient with a positive coefficient for $\mathrm{EBV}$ had a positive coefficient for Toxoplasma in a second aqueous humour sample and the coefficient for EBV was negative. The double positive coefficients in these cases might be caused by polyclonal $B$ cell activation. The diagnosis of the remaining six patients with a positive coefficient for EBV alone were multifocal chorioretinitis, panuveitis $(n=2)$, presumed ocular tuberculosis, and AIDS with retinitis $(n=2)$. Marginal positive coefficients were observed in the three patients with multifocal chorioretinitis, presumed ocular tuberculosis, and in one of the patients with AIDS and retinitis. The highest coefficient of 17 was detected in the vitreous fluid of a patient with panuveitis. Whether in these cases EBV participates in the pathogenesis of the ocular inflammation is not clear yet and is subject of further investigation.

\section{Human herpesvirus 6}

The prevalence of human herpes virus 6 (HHV6) is high in the normal population, with $50-90 \%$ of the adults having specific antibodies in the serum. In childhood, an infection usually results in exanthema subitum but other clinical features associated with HHV6 infection have not yet been fully established. ${ }^{71}$ Since HHV6 has been demonstrated in the retina of patients with AIDS and retinitis, ${ }^{72} 73$ we wanted to investigate whether local antibody production against HHV6 could be detected in this group of patients. The aqueous humour of 22 AIDS patients with retinitis, in the majority of cases caused by CMV and selected for positive antibody titres against HHV6 in the serum, were tested by immunofluorescence (HHV6 IgG IFA kit: Biotrin International, Dublin, Ireland). In four samples low antibody titres were detected resulting in a coefficient $<1$ and the other 18 aqueous humour samples were negative. Although these results are not indicative of an intraocular infection with HHV6, in patients with AIDS the absence of specific antibodies does not exclude the diagnosis. ${ }^{56}$

\section{Miscellaneous viruses}

Measles is usually a self limiting disease but might be complicated by several disorders - for instance, subacute sclerosing panencephalitis or retinopathy. ${ }^{64}$ BlochMichel et al reported positive coefficients for measles virus 
in aqueous humour of uveitis patients associated with multiple sclerosis, as well as in patients with idiopathic uveitis. ${ }^{75}$ The coefficients for the measles virus were significantly higher in samples from patients with multiple sclerosis, compared with the group with idiopathic uveitis. However, these results have not yet been confirmed by other investigators.

Recently, a new infectious uveitis entity has been described that appears to be associated with human $\mathrm{T}$ cell lymphotropic virus type 1 (HTLV-1). ${ }^{76}$ This virus is associated with adult $\mathrm{T}$ cell leukaemia or lymphoma and tropical spastic paraparesis. HTLV-1 DNA had been detected by PCR in 12 aqueous humour samples in Japanese patients with idiopathic uveitis. ${ }^{77} \mathrm{Local}$ antibody production against HTLV-1 in ocular fluids has not been reported.

It has been suggested that parvo B19 virus and adenoviruses play a role in the pathogenesis of intermediate uveitis. Infections with these viruses are common in the community. Parvo B19 virus is associated with erythema infectiosum or fifth disease and adenoviruses cause infections of the respiratory tract and epidemic keratoconjunctivitis. Witmer observed local antibody production against adenovirus in two patients with iritis and chronic cyclitis, respectively. ${ }^{36}$ We investigated serum aqueous humour or vitreous fluid of patients with intermediate uveitis for the presence of specific antibodies against adenovirus and parvovirus $(n=8$ and $n=6$, respectively). All these patients had positive serum titres against these viruses, but no local antibody production was observed. ${ }^{78}$

\section{Borrelia burgdorferi}

Various ocular manifestations of Lyme borrelioses have been reported including uveitis with vitreous clouding ${ }^{79-81}$ the benefit of serology against Borrelia is doubtful in the case of uveitis, since at an early stage in the disease serum titres are often negative and positive serology occurs in a normal population. ${ }^{82}$ In our laboratory, 95 paired aqueous humour or vitreous fluid and serum samples of patients with various uveitis entities (in the majority of the cases chronic intermediate or panuveitis of unknown origin) were investigated for the presence of anti-borrelia antibodies. Samples were tested by an immunofluorescence assay (Progen Biotechnik, Heidelberg, Germany). In most of the ocular fluid samples no specific antibodies against Borrelia were detectable. Twelve ocular fluid and serum samples were positive for specific antibodies, but in 11 cases the coefficient was negative and none of the patients fulfilled the diagnostic criteria for Lyme borreliosis. One coefficient in vitreous fluid was just above the cutoff level. However, this patient had no systemic evidence of Lyme borreliosis and, as a result false positivity of the coefficient cannot be excluded in this case.

\section{Treponema pallidum}

Syphilis is a venereal multisystem disease caused by an infection with Treponema pallidum. Ophthalmic manifestations of syphilis are numerous and usually associated with the secondary stage of the disease. ${ }^{8384}$ Treponemas have been detected in aqueous humour of patients with uveitis in secondary syphilis. ${ }^{85}$ Touboul et al investigated paired serum and aqueous humour samples of three patients with syphilitic uveitis in the fluorescent treponemal antibody absorption test (FTA). In one case the coefficient was $5 \cdot 2$, in the other two cases it was just under 3. In one of the latter cases the antibody titre declined in a second aqueous humour obtained after treatment. Despite these results, the authors conclude that the evaluation of anti-treponema antibodies in aqueous humour did not contribute to the diagnosis in these cases. $^{86}$

\section{Discussion}

Several studies have reported positive results for local antibody production in ocular fluids against various herpesviruses or parasites. Especially in the event of presumed ocular toxoplasmosis or ARN, performing a paracentesis and investigation of antibody titres against Toxoplasma and herpesviruses can confirm the diagnosis. Positive coefficients for CMV are mainly observed in samples from immunocompromised patients, but in patients with AIDS the stage of the HIV infection may be relevant for the humoral immune response. The role of EBV in the pathogenesis of uveitis is still not clear and results of studies on local antibody production against EBV did not clarify this issue. The moment of collecting the samples appears crucial, as several investigators reported negative results of samples obtained within 2 or 3 weeks after the onset of the disease. ${ }^{1024334445}$ In the event of negative coefficients, a second paracentesis can be considered after several weeks if the diagnosis is still doubtful.

A remarkable observation is that various studies report double positive coefficients for different herpesviruses. The question arises whether these multiple positive coefficients are caused by cross reactivity between viruses, polyclonal B cell activation or by a double infection with different herpesviruses. Support for the latter is the detection of CMV and HSV in the retina and CMV DNA and HSV DNA in the aqueous humour of patients with AIDS and retinitis, but in these cases the patients were immunocompromised. ${ }^{6087}$ Unfortunately, histological examination of the eyes during the active stage of inflammation to provide an answer to these questions is generally not available.

In contrast with herpesviruses and Toxoplasma, local antibody production against bacterial agents, except for antibodies against Treponema pallidum, ${ }^{86}$ was generally negative. ${ }^{20} 36$ One explanation might be that bacterial agents are not a frequent cause of uveitis. Another possibility is that in the event of a systemic bacterial infection ocular inflammation is caused by a secondary autoimmune reaction rather than an intraocular penetration of bacteria. However, the presence of spirochaetes in aqueous humour has been observed in patients with syphilis and uveitis. ${ }^{85}$ Recently, Leptospira DNA was detected by PCR in aqueous humour of a patient with uveitis, while the acute systemic infection with Leptospira had occurred 9 years previously. ${ }^{88}$ Negative serology against bacterial agents in ocular fluids may also be caused by the use of inappropriate or insensitive assays. In future, the use of more accurate and sensitive assays may result in the detection of local antibody production against bacterial agents in ocular fluids.

Many questions still remain concerning the pathogenesis of the disease, specifically the involvement of autoimmune mechanisms in microbe induced uveitis. It is the general opinion that uveitis is a $\mathrm{T}$ cell mediated disease and $T$ cells are the most common infiltrating cells in ocular fluids during inflammation. ${ }^{15-1789}$ Therefore, $T$ cells in the eye should be further characterised and tested for their antigen specificity. These studies might provide an answer to the question whether autoimmune mechanisms participate at a late stage of microbe induced uveitis and may lead to new therapeutic strategies.

In some of the studies reviewed here, the detection of local antibody production was in contrast with the 
presumed clinical diagnosis and resulted in a change of medical treatment. Although the position of a paracentesis in the diagnostic process of uveitis is not yet elucidated, we do recommend aqueous analysis in cases with an ambiguous clinical presentation with presumed infectious aetiology, or in cases in which examination of the fundus is hindered by vitreous opacities. However, many questions concerning disease pathogenesis - for instance, whether intraocular infections with multiple herpesviruses occur in uveitis and whether Toxoplasma plays a role in some cases of anterior uveitis, remain unanswered. Local antibody production in combination with the PCR technique on ocular fluid samples or histological examination of chorioretinal biopsies may provide an answer to these questions in the future. ${ }^{90}$

J H DE BOER
L LUYENDIJK
A ROTHOVA
A KIJLSTRA

The Netherlands Ophthalmic Research Institute,

PO Box 12141, 1100 AC Amsterdam

A KIJLSTRA

Department of Ophthalmology

University of Amsterdam

A ROTHOVA

Department of Ophthalmology,

University of Utrecht,

The Netherlands

1 Rothova A, Buitenhuis HJ, Meenken C, Brinkman CJ, Linssen A, Alberts $\mathrm{C}$, et al. Uveitis and systemic diseases. Br F Ophthalmol 1992; 76: 137-41.

2 Barton $\mathrm{K}$, Pavesio CE, Towler HMA, Lightman S. Uveitis presenting de novo in the elderly. Eye 1994; 8: 288-91.

3 Rosenbaum JT. Uveitis. An internist's view. Arch Intern Med 1989; 149: 1173-6.

4 Nussenblatt RB, Palestine AG. In: Uveitis. Fundamentals and clinical practice. Chicago: Year Book Medical Publishers, 1989: 21-52.

5 Saari KM. Acute anterior uveitis. In: Saari KM, ed. Uveitis update. Amsterdam: Excerpta Medica, 1984: 79-80.

6 Yoser SL, Forster DJ, Rao NA. Systemic viral infections and their retinal and choroidal manifestations. Surv Ophthalmol 1993; 37: 313-52.

7 O'Connor GR. Factors related to the initiation and recurrences of uveitis. Am F Ophthalmol 1983; 96: 577-98.

8 Nussenblatt RB, Mittal KK, Fuhrman S, Sharma SD, Palestine AG. Lymphocyte proliferative responses of patients with ocular toxoplasmosis to parasite and retinal antigen. Am f Ophthalmol 1989; 197: 632-41.

9 Rothova A. Ocular involvement in toxoplasmosis. Br f Ophthalmol 1993; 77: 371-7.

10 Pepose JS, Flowers B, Stewart JA, Grose C, Levy DS, Culbertson WW, et al. Herpesvirus antibody levels in the etiologic diagnosis of the acute et al. Herpesvirus antibody levels in the etiologic diagnosis of
retinal necrosis syndrome. Am $₹$ Ophthalmol 1992; 113: 248-56.

11 Nussenblatt RB, Palestine AG. In: Uveitis. Fundamentals and clinical practice. Chicago: Year Book Medical Publishers, 1989: 80-93.

12 De Grandmont GM. Nature microbienne des ophthalmies profondes. Arch Ophthalmol 1892; 12: 623-6.

13 Amsler $M$, Verrey $F$, Huber $A$. L'humeur aqueuse et ses fonctions. Rapport a la Société Française Ophtalmologique. Paris: Masson, 1955.

14 Brückner A. Cytologische studien am menschlichen Auge. Graefes Arch Ophthalmol 1919; 100: 179-327.

15 Von Sallman L, Locke JC, Locke BD. Cytological and bacteriological studies of the aqueous humor in uveitis. Arch Ophthalmol 1951; 46: 4-13.

16 Hogan MJ, Wood IS, Godfrey WA. Aqueous humor cytology in uveitis.

Arch Ophthalmol 1973; 89: $217-20$.
17 Belfort R, Moura NC, Mendes NF. T and B lymphocytes the aqueous humor of patients with uveitis. Arch Ophthalmol 1982; 100: 465-7.

18 Davis JL, Solomon D, Nussenblatt RB, Palestine AG, Chan CC. Immunocytochemical staining of vitreous cells. Ophthalmology 1992; 99: 250-6.

19 von Goldmann H, Witmer R. Antikörper im Kammerwasser. Ophthalmologica 1954; 127: 323-30.

20 Dussaix E, Cerqueti PM, Pontet F, Bloc-Michel E. New approaches to the detection of locally produced antiviral antibodies in the aqueous of patients with endogenous uveitis. Ophthalmologica 1987; 194: 145-9.

21 Luyendijk L, van der Horn CJ, Visser OHE, Suttorp-Schulten MSA, van der Biesen PR, Rothova A, et al. Detection of locally produced antibodies to herpesviruses in the aqueous humour of patients with acquired immune deficiency syndrome (AIDS) or acute retinal necrosis syndrome immune deficiency syndrome (AIDS)

22 O'Connor GR. Antitoxoplasma precipitin in aqueous humor. New application of the agar diffusion technique. Arch Ophthalmol 1957; 57:52-7.

23 O'Connor GR. Precipitating antibody to Toxoplasma: a follow-up study on findings in the blood and aqueous humor. Am $\mathcal{F}$ Ophthalmol 1957; 44: 75-85.

24 Desmont G. Definitive serological diagnosis of ocular toxoplasmosis. Arch Ophthalmol 1966; 76: 839-51.

25 Rehder JR, Burnier M, Pavesio CE, Kim MK, Riguerio M, Petrilli AM, et al. Acute unilateral toxoplasmic iridocyclotis in an AIDS patient. $A m \mathcal{F}$ Ophthalmol 1988; 106: 740-1.

26 Gawked EL, Bloch-Michel E. Interest de laded datal de la serologic quantitative de l'humeur aqueuse pour le diagnostic de la toxoplasmose oculaire. A propos de 180 cas. F Fr Ophtalmol 1980; 3: 21-6.

27 Kijlstra A, Luyendijk L, Baarsma GS, Rothova A, Schweitzer CMC, Timmerman $\mathrm{Z}$, et al. Aqueous humor analysis as a diagnostic tool in toxoplasma uveitis. Int Ophthalmol 1989; 13: 383-6.
28 Kijlstra A, Breebaart AC, Baarsma GS, Bos PJM, Rothova A, Luyendijk L, et al. Aqueous chamber taps in toxoplasma chorioretinitis. Doc Ophthalmol 1986; 64: 53-8

29 Luyendijk L, de Boer JH, Rothova A, Baarsma GS, de Jong PTVM, vd Horn GJ, et al. Sensitivity and specificity of anti-viral antibody determination in the aqueous or vitreous of uveitis patients. In: Dernouchamps JP, Verougstraete C, Caspers-Velu L, Tassignon MJ, eds. Recent advances in uveitis. Amsterdam/New York: Kugler Publications, 1992: 265-7.

30 Baarsma GS, Luyendijk L, Kijlstra A, de Vries J, Peperkamp E, Merten DAE, et al. Analysis of local antibody production in the vitreous humor of patients with severe uveitis. Am f Ophthalmol 1991; 112: 147-50.

31 Brezin AP, Eqwuagu CE, Silveira C, Thulliez $\mathrm{Ph}$, Martins MC, Mahdi RM, et al. Analysis of aqueous humor in ocular toxoplasmosis. $N \mathrm{Engl} f \mathrm{Med}$ 1991; 10: 699.

32 Aouizerate F, Cazenave J, Poirier L, Verin $\mathrm{Ph}$, Cheyrou A, Begueret J, Lagoutte F. Detection of Toxoplasma gondii in aqueous humor by the polymerase chain reaction. Br f Ophthalmol 1993; 77: 107-9.

33 Pederson O, Lorentzen-Styr A. Antibodies against Toxoplasma gondii in the aqueous humor of

34 Searl SS, Moazed K, Albert DM, Marcus LC. Ocular toxocariasis presenting as leukocoria in a patient with low ELISA titer to Toxocara canis. Ophthalmology 1981, 88: 1302-6.

35 Biglan AW, Glickman AJ, Lobes LA. Serum and vitreous Toxocara antibody in nematode endophthalmitis. Am $f$ Ophthalmol 1979; 88: 898-901.

36 Witmer R. Clinical implications of aqueous humor studies in uveitis Am $\mathcal{F}$ Ophthalmol 1978; 86: 39-45.

37 Duker JS, Blumenkranz MS. Diagnosis and management of the acute retinal necrosis (ARN) syndrome. Surv Ophthalmol 1991; 35: 327-43.

38 Culbertson WW, Blumenkranz MS, Pepose JS, Stewart JA, Curtin VT. Varicella zoster virus is a cause of the acute retinal necrosis syndrome. Ophthalmology 1986; 93: 559-69.

39 Freeman WR, Thomas EL, Rao NA, Pepose JS, Trousdale MD, Howes EL, et al. Demonstration of herpes group virus in acute retinal necrosis EL, et al. Demonstration of herpes group virus

40 Soushi S, Ozawa H, Matsuhashi M, Shimazaki J, Saga U, Kurata T Demonstration of varicella-zoster virus antigens in the vitreous aspirates of patients with acute retinal necrosis syndrome. Ophthalmology 1988; 95: 1394-8.

41 Usui $M$. Clinical evaluation of herpes viral antibody in aqueous humor of Kirisawa's uveitis. Folia Ophthalmol fpn 1988; 92: 1398-405.

42 Azazi M, Samuelsson A, Line A, Forsgren M. Intrathecal antibody production against viruses of the herpes family in acute retinal necrosis syndrome. Am f Ophthalmol 1991; 112: 76-82.

43 Gartry DS, Spalton DJ, Tilzey A, Hykin PG. Acute retinal necrosis syndrome. Br f Ophthalmol 1991; 75: 292-7.

44 de Boer JH, Luyendijk L, Rothova A, Baarsma GS, de Jong PTVM, Bollemeijer JG, et al. Detection of intraocular antibody production to herpesviruses in acute retinal necrosis syndrome. Am $\mathcal{F}$ Ophthalmol 1994 117: $201-10$

45 Usui $M$, Usui $N$, Goto $H$, Minoda $H$, Rai T. Polymerase chain reaction for diagnosis of herpetic intraocular inflammation. Orul Immuno Inflammation 1993; 1: 105-12.

46 Nishi M, Hanashiro R, Mori S, Masuda K, Mochizuki M, Hondo R. Polymerase chain reaction for the detection of the varicella-zoster genome in ocular samples from patients with acute retinal necrosis. $A m$ Ophthalmol 1992; 114: 603-9.

47 Thompson WS, Culbertson WW, Smiddy WE, Robertson JE, Rosenbaum JT. Acute retinal necrosis caused by reactivation of herpes simplex virus T. Acute retinal necrosis caused by reactivatio
type Am f Ophthalmol 1994; 118: 205-11.

48 Lewis ML, Culbertson WW, Post JD, Miller D, Kokame GT, Dix RD. Herpes simplex virus type 1 : a cause of the acute retinal necrosis syndrome. Ophthalmology 1989; 96: 875-8.

49 Carney MD, Peyman GA, Goldberg ME, Pako K, Pulido J, Nicholson D. Acute retinal necrosis. Retina 1986; 6: 85-94.

50 Matsuo T, Date S, Tsuji T, Koyama M, Nakayama T, Koyama T, et al. Immune complex containing herpesvirus antigen in a patient with acute retinal necrosis. Am $\mathcal{F}$ Ophthalmol 1986; 101: 368-71.

51 Denis J. Immunological study of the aqueous humor in ocular herpes simplex. In: Streiff EB, ed. Modern problems in ophthalmology. Basel: Karger, 1976; 16: 220-4.

52 England AC, Miller SA, Maki DG. Ocular findings of acute cytomegalovirus infection in an immunologically competent adult. $N$ Engl 7 Med 1982; 8: 94-5.

53 Chawla HB, Ford MJ, Munro JF, Scorgie RE, Watson AR. Ocular involvement in cytomegalovirus infection in a previous health adult. $B M F 1976$; 2: $281-2$.

54 Burns RP. Cytomegalic inclusion disease uveitis. Report of a case with isolation from aqueous humor of the virus culture. Arch Ophthalmol 1959, 61: 376-8.

55 Bachman DM, Rodriques MM, Chu FC, Straus DG, Macher AM. Culture-proven cytomegalovirus retinitis in a homosexual man with acquired immunodeficiency syndrome. Ophthalmology 1984; 89: 797-804.

56 Porter SB, Sande MS. Toxoplasmosis of the central nervous system in the acquired immunodeficiency syndrome. N Engl ₹ Med 1992; 327: 1643-8.

57 Fox GF, Crouse CA, Chuang EL, Pflugfelder SC, Clearly TJ, Nelson SJ, et al. Detection of herpes virus DNA in vitreous and aqueous specimens by the polymerase chain reaction. Arch Ophthalmol 1991; 266: 266-72.

58 Michell SM, Fox JD, Tedder RS, Gazzard BG, Lightman S. Vitreous sampling and viral genome detection for the diagnosis of viral retinitis in patients with AIDS. F Med Virol 1994; 43: 336-40.

59 Gerna G, Baldanti F, Sarasini A, Furione M, Percivalle E, Revello GM et $a l$, and The Italian Foscarnet Study Group. Effect of foscarnet induction treatment on quantitation of human cytomegalovirus (HCMV) DNA in peripheral blood polymorph nuclear leukocytes and aqueous humor of AIDS patients with HCMV retinitis. Antimicrob Agents Chemother 1994 38: $30-44$.

60 Garweg J, Fenner T, Böhnke M, Schmitz H. An improved technique for the diagnosis of viral retinitis from samples of aqueous humor and vitreous. Graefes Arch Chin Exp Ophthalmol 1993; 231: 508-13. 
61 Fleischer GR. Epstein-Barr virus. In: Belshe RB, ed. Textbook of human virology. Littleton, MA: PSG Publishing Co, 1984: 853.

62 Matoba AY. Ocular disease associated with Epstein-Barr virus infection. Surv Ophthalmol 1990; 35: 145-50.

63 Aaberg TM, O'Brien WJ. Expanding ophthalmologic recognition of Epstein-Barr virus infections. Am f Ophthalmol 1987; 104: 420-2.

64 Raymond LA, Wilson CA, Linnemann Jr CC, Ward MA, Bernstein DI, Love DC. Punctate outer retinitis in acute Epstein-Barr virus infection. Am ₹ Ophthalmol 1987; 104: 424-6.

65 Wong KW, D'Amico DJ, Hedges TR, Soong HK, Schooley RT, Kenyon KR. Ocular involvement associated with chronic Epstein-Barr virus disease. Arch Ophthalmol 1987; 105: 788-92.

66 Tiedeman JS. Epstein-Barr virus antibodies in multifocal chorioiditis and panuveitis. Am f Ophthalmol 1987; 103: 659-63.

67 Spaide RF, Sugin S, Yannuzzi LA, DeRosa JT. Epstein-Barr virus antibodies in multifocal chorioretinitis and panuveitis. Am f Ophthalmol 1991, 112: 410-3.

68 Nolle B, Eckardt C. Vitrectomy in multifocal chorioretinitis. Germ $\mathcal{f}$ Ophthalmol 1993; 2: 14-9.

69 Usui M, Sakai J. Three cases of EB virus-associated uveitis. Int Ophthalmol 1990; 14: 371-6.

70 Maas S, Deutman AF, Rademakers AJM, Kijlstra A. Diagnostic and therapeutic trans pars plana vitrectomy in uveitis. In: Stripe $\mathbf{M}$, ed. Advances in vitreoretinal surgery. Rome: Fondazione GB Bietti per L'Ophthalmologia, 1992: 173-5.

71 Morris DJ, Path MRC. Primary human herpesvirus 6 infection in an adult. Morris DJ, Path MRC. Primary hum

72 Qavi HB, Green MT, SeGall GK, Font RL. Demonstration of HIV-1 and HHV-6 in AIDS-associated retinitis. Curr Eye Res 1989; 8: 379-87.

73 Reux I, Fillet AM, Agut H, Katlama C, Hauw J, Lehoang P. In situ detection of human herpesvirus 6 in retinitis associated with acquired immunodeficiency syndrome. Am 7 Ophthalmol 1992; 114: 375-7.

74 Maltia M, Tarkkanen A, Vaheri A, Paetau A, Kaakinen K, Erkkila H. Measles retinopathy during immunosuppression. $\mathrm{Br}$ f Ophthalmol 1978; 62: 356-60.

75 Bloch-Michel E, Helleboid L, Hill C, Koscienly S, Dussaix E. Antibodies to measles virus in the aqueous humor of patients with uveitis associated to multiple sclerosis. Lancet 1992; 339: 750-1.
76 Mochizuki M, Watanabe T, Yamaguchi K, Yoshimura Knakashima S, Shirao M, Araki S, et al. Uveitis associated with human T-cell lymphotropic virus type I. Am f Ophthalmol 1992; 114: 123-9.

77 Mochizuki M, Yamaguchi K, Takatsuki K, Watanabe T, Mori S, Tajima K. HTLV-1 and uveitis. Lancet 1992; 339: 1110.

78 de Boer JH, de Keizer RJW, Kijlstra A. In search of intraocular antibody production to parvo B19 virus and adenovirus in intermediate uveitis. Br F Ophthalmol 1993; 77: 829.

79 Winward KE, Smith JL, Culbertson WW, Paris-Hamelin A. Ocular Lyme borreliosis. Am f Ophthalmol 1989; 108: 651-7.

80 Kuiper H, Koelman JHTM, Jager MJ. Vitreous clouding associated with Lyme borreliosis. Am f Ophthalmol 1989; 108: 453-4.

81 Rothova A, Kuper H, Spanjaard L, Dankert J, Breebaart AC. Spiderweb vitritis in Lyme borreliosis. Lancet 1991; 337: 489-90.

82 Breeveld J, Kuiper H, Spanjaard L, Luyendijk L, Rothova A. Uveitis and Lyme borreliosis. Br f Ophthalmol 1993; 77: 480-1.

83 Nussenblatt RB, Palestine AG. In: Uveitis. Fundamentals and clinical practice. Chicago: Book Medical Publishers, 1989: 388-406.

84 Margo CE, Hamed LF. Ocular syphilis. Surv Ophthalmol 1992; 37: 203-20.

85 Hira SK, Shukla SM, Mubanga MR. Uveitis in secondary syphilis: a report of treponemes in aqueous humour. Eur 7 Sex Transmit Dis $1985 ; 2: 107-9$.

86 Touboul JP, LeHoang P, Fontaine M, Wechsler, Cabane J, Godeau P, et al. Uveitis auc ours de la syphilis acquise. 7 Fr Ophtalmol 1985; 8: 321-31.

87 Pepose JS, Hilborne LH, Cancilla PA, Foos RY. Concurrent herpes simplex and cytomegalovirus retinitis and encephalitis in the acquired immune
deficiency syndrome (AIDS). Ophthalmology 1972; 91: 1669-77.

88 Merien F, Perolar P, Mancel E, Persan D, Baraton G. Detection of Leptospira DNA by polymerase chain reaction in aqueous humor of a patient with unilateral uveitis. F Infect Dis 1993; 168: 1335-6.

89 Forrester JV. Uveitis: pathogenesis. Lancet 1991; 338: 1498-501.

90 Nussenblatt RB. Use of chorioretinal biopsies in the diagnosis of uveitis. In: Dernouchamps JP, Verougstraete C, Caspers-Velu L, Tassignon MJ, eds. Recent advances in uveitis. Amsterdam/New York: Kugler Publications, 1992: 455-8.

91 Greven CM, Teot LA. Cytologic identification of Toxoplasma gondii from vitreous fluid. Arch Ophthalmol 1994; 112: 1086-8. 